\title{
Yabancı Dil Olarak Türkçe Öğretiminde Eğitsel Oyunların Kullanımının Akademik Başarı, Tutum ve Kalıcılığa Etkisi*
}

\author{
Sedat Erol $^{* *}$, Ilhan Erdem ${ }^{* * *}$, Ahmet Akkaya**** \\ Makale Geliş Tarihi:30/12/2020 \\ Makale Kabul Tarihi: 28/02/2021 \\ DOI: $10.35675 /$ befdergi.850249
}

$\ddot{O} z$

$B u$ araştırmanın amacl, eğitsel oyunların yabancı dil olarak Türkçe öğretiminde kazanımlara ulaşmada, öğrencinin başarısına, derse karşı tutumuna ve öğrenilenlerin kalıcılığına etkisini belirlemektir. Araştırmanın çalışma grubu, 2018-2019 eğitim-öğretim yılında, Adlyaman Halk Eğitim Merkezinde, başlangıç (A1) düzeyinde yabancı dil olarak Türkçe öğrenen 8-12 yaş grubundaki ögrrencilerden seçilmiştir. Eşleştirilmiş ön test- son test kontrol gruplu yarı deneysel desenin kullanıldığı araştırmada veri toplama aracı olarak, Erol (2019) tarafindan geliştirilen "Başlangıç (A1) Düzeyi Türkçe Yeterlik Sinavı" ve "Yabancı Dil Olarak Türkçe Öğrenen Çocuklara Yönelik Tutum Ölçeği” kullanılmıştır. Araştırma sonucunda, yabancı dil olarak Türkçe ögrretiminde eğitsel oyunların kullanımının öğrenci başarısını artırdığı, kalıcı öğrenme ve olumlu tutum geliştirmeyi să̆ladığı sonucuna ulaşılmışıtır.

Anahtar Kelimeler: Eğitsel oyun, Türkçe, yabancı dil, yöntem ve teknikler

\section{The Effects of the Use of Educational Games in Teaching Turkish as a Foreign Language on Academic Achievement, Attitude and Retention}

\begin{abstract}
The aim of this research is to determine the effect of educational games on achievement of students in teaching Turkish as a foreign language, student's success, attitude towards the course and permanence of knowledge learned. The study group of the study was selected from 8-12 year old students learning Turkish as a foreign language at the Beginner (A1) Level in Adlyaman Public Education Center in 2018-2019 academic year. Paired pretest-posttest control group quasi-experimental design was used as the data collection tool, as the "Beginner Level (A1) Turkish Proficiency Exam" and "Attitude Scale for Children Learning Turkish as a Foreign Language" developed by Erol (2019). As the result of the study, it was concluded that the use of educational games in teaching Turkish as a foreign language increases student achievement and provides permanent learning and positive attitude development.

\footnotetext{
* Bu çalıșma İlhan ERDEM ve Ahmet AKKAYA danıșmanlığında Sedat EROL tarafindan hazırlanan "Yabancı Dil Olarak Türkçe Öğretiminde Eğitsel Oyunların Kullanımı" (İnönü Üniversitesi, Eğitim Bilimleri Enstitüsü) başlıklı doktora tezinden üretilmiştir.

** Adıyaman Üniversitesi, Adıyaman, Türkiye, sedaterol02@hotmail.com, ORCID: 0000-0003-08409903

*** İnönü Üniversitesi, Malatya, Türkiye, ilhan.erdem@inonu.edu.tr, ORCID: 0000-0002-4244-6225

**** Adıyaman Üniversitesi, Adıyaman, Türkiye, aakkaya@adiyaman.edu.tr, ORCID: 0000-0003-38458992 iD
}

Kaynak Gösterme: Erol, S., Erdem, İ. \& Akkaya, A. (2021). Yabancı dil olarak Türkçe öğretiminde eğitsel oyunların kullanımının akademik başarı, tutum ve kalıcılığa etkisi. Bayburt Ĕ̆itim Fakültesi Dergisi, 16(Özel Say1), 166-183. https://doi.org/10.35675/befdergi.850249 
Keywords: Educational game, foreign language, methods and techniques, Turkish

\section{Giriş}

"Kişinin ailede ve içinde büyüdüğü toplumda edindiği ilk dil” (Vardar, 2002, s. 17) ana dilidir. Bireyin çevresiyle sağlıklı iletişim kurmasında şüphesiz ana dilini doğru, güzel ve etkili kullanması önemli bir durumdur. Bununla birlikte bireyler ve toplumlar arası ilişkilerin yoğunlaştığı, teknolojik gelişmelerle iletişim ağının genişlediği ve anlık iletişimin kurulduğu bu çağda, artık yabancı dil öğrenme isteğinin, yabancı dil öğrenme ihtiyacına dönüştüğü görülmektedir.

Dünyada geniş coğrafyada konuşulan diller arasında önemli bir yeri olan Türkçenin ana dili olarak kullanıldığı ülkelerin başında yer alan Türkiye'de, Türkçenin yabancı dil olarak öğretimi/öğrenimi için önemli çalışmalar yürütülmektedir. Fakat Türkçenin yabancı dil olarak öğretiminde her ne kadar uzun bir süre geçmiş olsa da çalışmaların sistemli bir şekilde yürütülemediği ve birtakım zorluklar yaşandığı görülmektedir (Göçer \& Moğul, 2011). Özellikle son dönemlerde başta göçler olmak üzere turizm, ticaret, eğitim gibi faktörlerin etkisiyle Türkçeye duyulan ilgi ve ihtiyaç artmış; yabancı dil olarak Türkçe öğretimi/öğrenimi alanında önemli çalışmalar yapılmıştır. $\mathrm{Bu}$ süreçte farklı ana diline, yaş grubuna ve özelliklere sahip bireylerin Türkçe öğrenirken birtakım sorunlar yaşaması, yabancı dil olarak Türkçe öğretiminde kullanılan yöntem ve tekniklerin sorgulanmasına sebep olmuştur. Bu sorgulama sonucunda öğrenci merkezli, iletişim temelli, bireysel farklılıkları dikkate alan ve temel becerilerin kullanımına imkân sağlayarak kalıcı öğrenmeyi gerçekleştiren öğretim yöntem ve teknikleri üzerinde durulmuştur.

Dil öğretiminde temel becerileri kullanarak kalıcı öğrenmeleri sağlamak öğrenci açısından kolay bir süreç değildir. Öğrencinin bu süreçte başarılı olabilmesi için öğrenmeye ilgi duyması, çaba sarf etmesi ve bu çabayı uzun süre devam ettirebilmesi gereklidir. Bu bağlamda eğitsel oyunlar öğrencileri güdüleyen, onlara yoğun ve anlamlı öğrenme ortamları oluşturarak yardımcı olan vazgeçilmez etkinliklerdir (Wright, Betteridge \& Buckby, 2006, s. 2; Lee, 1995, s. 35). Öğrencilerin sıkıcı bulduğu konuları ilgi çekici bir hâle getiren, akıcılığı teşvik eden oyunlar eğlendirir, öğretir ve teşvik eder. Bu nedenlerden herhangi biri olmasa da öğrencilerin sadece güzelliği yabancı bir dilde görmelerine yardımcı oldukları için oyunların kullanılması gerekir (Uberman, 1998, s. 21; Simpson, 2015).

Dil öğrenimi süreci ilgi çekici ve eğlenceli olmalıdır. Bu bakımdan eğitsel oyunlar dil öğreniminde kullanılabilecek önemli bir tekniktir. Fakat eğitsel oyunlar sadece eğlenme amacı taşıyan etkinlikler olmayıp aynı zamanda ișlevsel ve belirgin bir amaca sahiptir. Bu amaç doğrultusunda öğrenci dil öğrenim sürecinde aktif olur ve temel becerilerini kullanarak anlamlı öğrenmeler gerçekleştirir (Bumpass, 1963, s. 143; Lee, 1986, s. 1). Eğitsel oyunların kullanıldı̆̆ı öğretim ortamlarında öğrencilerin kaygıları azalır ve öğrenciler kendilerini daha rahat hisseder. Bununla birlikte, eğlendirici özellikler taşıyan oyunlar öğrencilerin güdülenmesini ve öğrenme ortamında aktif bir duruma gelmesini sağlar (Richard-Amato, 1988, s. 147; Hansen, 1994, s. 118; Wierus \& Wierus, 1994, s. 218'den Akt. Uberman: 1998, s. 21). Böylece öğrenme daha hızlı ve kalıcı bir şekilde gerçekleşir. Bu özellikler doğrultusunda eğitsel oyunlar, öğrenim sürecini eğlenceli bir hâle getiren, 
öğrencilerin dilsel, zihinsel, duyuşsal ve sosyal becerilerini geliştiren amaçlı etkinlikler şeklinde tanımlanabilir.

Eğitsel oyunlar, öğrencilerin sorumluluk bilinci kazanma, iletişim kurma, kendini ifade etme, dikkat, strateji geliştirme, güzel konuşma ve karar verme gibi birçok becerisinin gelişimi için uygun öğrenme ortamları oluşturur (Taşpınar, 2012, s. 240). Anlama, anlatma, dönüt verme gibi iletişimsel unsurlar, eğitsel oyunlar aracılığıyla öğrenme ortamında kullanılır ve öğrenme ortamı zenginleştirilir (Larsen Freeman, 2000, s. 126; Mubaslat, 2012, s. 12).

Eğitsel oyunlar, öğrenmeye yönelik olan ve bir amaç doğrultusunda gerçekleştirilen eğlendirici, ilgi çekici, etkileşime açık etkinliklerdir (Wright vd. 2006: 1; Demirel, 2011: 85). Eğitsel oyunlar, dili etkin kılan canlı bir iletişim ortamına sahiptir. Duygu ve düşünceleri içerisinde barındıran oyunlar sayesinde dil anlamlı bağlamlar içerisinde kullanılır ve daha canlı bir öğrenme ortamında öğrencilerin deneyim sahibi olmaları sağlanır.

Yabancı dil olarak Türkçe öğretimi/öğrenimi sürecinde eğitsel oyunların kullanımı, öğrenci merkezli ve aktif bir öğretim metodu olmasından dolayı gittikçe yaygınlaşmaktadır (Kara, 2010, s. 409). Özellikle yabancı dil öğrenme sürecinde en önemli sorunlardan biri olan "yöntem ve teknik" sorununda tekdüzeliği ortadan kaldırması ve zengin öğrenme ortamları sunması, oyunların ilgi çekici bir öğretim aracı olarak kullanılmasını sağlamaktadır (Erdem ve Aycan, 2017).

Eğitsel oyunlar yabancı dil olarak Türkçe öğretimi/öğrenimi sürecinde özellikle temel düzeyde öğrencilerin birçoğunda görülen özgüven eksikliği, yetersizlik algısı, çekingenlik vb. sorunların çözümünde önemli bir rol üstlenir. Eğitsel oyunlarla öğrenciler bir yandan bu sorunları aşar, diğer yandan temel becerilerini kullanarak öğrenim sürecinin aktif bir parçası olur. Ayrıca bulunduğu toplumun kültürel kodlarını taşıyan oyunlar, dil öğretiminde önemli bir kültür aktarım aracı olarak da kullanilabilir.

Öğrenciye aktif olma, gerçek hayata yakın bir öğrenme ortamında iletişim kurma ve eğlenerek öğrenme imkânı sağlayan; öğrencinin dilsel, zihinsel, duygusal ve sosyal gelişimini destekleyen eğitsel oyunlar yabancı dil olarak Türkçe öğretiminde yaşanan yöntem ve teknik sorununun çözümünde kullanılabilecek önemli bir tekniktir. Yapılan alanyazın taramasında eğitsel oyunların Türkçenin ana dili olarak öğretiminde, yabancı dil olarak İngilizce, Fransızca, Arapça, Almanca gibi dillerin öğretiminde kullanımı ile ilgili birçok araştırmaya rastlanmıştır. Fakat eğitsel oyunların yabancı dil olarak Türkçe öğretiminde kullanımı ile ilgili çok sınırlı sayıda çalışma olduğu, bu çalışmalar içerisinde eğitsel oyun tekniğinin dil becerilerinin gelişimine ve öğrenci tutumuna etkisini ölçmeyi amaçlayan deneysel bir çalışmanın bulunmadığ 1 tespit edilmiştir. Bu bağlamda araştırmanın problem cümlesi "Yabanc1 dil olarak Türkçe öğretiminde eğitsel oyunların kullanımı öğrenci başarısı ve tutumunu, öğrenilenlerin kalıcılığını nasıl etkilemektedir?” şeklinde belirlenmiştir.

\section{Araştırmanın Amacı}

$\mathrm{Bu}$ araştırmanın amacı, eğitsel oyunların yabancı dil olarak Türkçe öğretiminde kazanımlara ulaşmada öğrencinin başarısına, derse karşı tutumuna ve öğrenilenlerin 
kalıcılığına etkisini belirlemektir. $\mathrm{Bu}$ amaç doğrultusunda araştırma süresince aşağıdaki sorulara cevap aranmıştır:

1. Yabancı dil olarak Türkçe öğretiminde eğitsel oyunlarla yapılan öğretim ile geleneksel yöntem ve tekniklerle yapılan öğretim arasında öğrenci başarı düzeyi ve öğrenilenlerin kalıcılığı açısından anlamlı bir farklılık var mıdır?

2. Yabancı dil olarak Türkçe öğretiminde eğitsel oyunlarla öğretimin uygulandığı deney grubuyla geleneksel yöntem ve tekniklerle öğretimin uygulandığ kontrol grubunun Türkçe dersine yönelik tutumları arasında anlamlı bir farklılık var midir?

\section{Araştırmanın Önemi}

Türkçenin yabancılara iletişim dili olarak sistemli bir şekilde öğretimi çok yakın bir tarihe kadar önemsenmemiştir. Bu konu Avrupa Topluluğuna üye olabilme çabaları içerisinde fark edilerek ön plana çıkarılmıştır. Bununla birlikte son dönemlerde başta göçler olmak üzere turizm, ticaret, eğitim gibi önemli faktörlerin etkisiyle Türkçeye duyulan ilgi ve ihtiyaç artmış, yabancı dil olarak Türkçe öğretimi/öğrenimi önem kazanmıştır. Kısa sürede hızlı bir şekilde gelişen bu olaylar sonucunda Türkçenin yabancı dil olarak öğretimi/öğrenimi alanında bazı sorunlar yaşanmıştır. Farklı özelliklere sahip öğrencilere yönelik farklı yöntem ve tekniklerin işe koşulmaması bu sorunların başında gelmektedir. Özellikle ilgi, istek ve gereksinimleri yetişkinlerden çok farklı olan çocukların Türkçe öğreniminde yaşadıkları sorunlar ön plana çıkmıştır. Bu bağlamda yabancı dil olarak Türkçe öğretiminde kullanılan tekniklerden biri olan eğitsel oyunların etkinliklerde yer alması önemli bir durumdur. Özellikle kendini ve dünyayı keşfetme isteğinde olan çocuklara eğlenceli bir öğrenme ortamı sunan, güdülenmeyi ve aktif katılımı sağlayan eğitsel oyunlar, dil öğreniminde öğrenci ve iletişim merkezli öğrenme ortamları oluşturur. Dilin anlamlı bağlamlar içerisinde öğrenilmesine imkân sağlar. Bununla birlikte, eğitsel oyunlar yabancı dil olarak Türkçe öğretiminde temel düzeyde (A1-A2) bulunan bütün yaş gruplarında bilginin somutlaştırılmasında kullanılabilecek işlevsel bir tekniktir.

\section{Yöntem}

$\mathrm{Bu}$ bölümde araştırma modeli, çalışma grubu, veri toplama araçları, verilerin toplanması ve analiz edilmesi süreci ile ilgili bilgilere yer verilmiştir.

\section{Araştırma Modeli}

Eğitsel oyunların yabancı dil olarak Türkçe öğretiminde kullanımının öğrenci başarısı ve tutumu üzerindeki etkisini tespit etmeyi amaçlayan bu araştırmada eşleştirilmiş ön test- son test kontrol gruplu yarı deneysel desen kullanılmıştır. Eşleştirilmiş ön test-son test kontrol gruplu modelde, eşleştirme yoluyla oluşturulmuş biri deney, diğeri kontrol grubu olmak üzere iki grup bulunur. Eşleştirme işleminde, başarı puanıyla birlikte yaş, cinsiyet gibi araştırmada kullanılacak değişkenler de göz önünde bulundurulur. Eşleştirilen bireyler kontrol ve deney gruplarına rastgele atanır. Her iki grupta da deneysel işlemden önce ve sonra ölçmeler yapılır (Fraenkel \& Wallen, 2006). Bu bağlamda araştırma sürecinde 5 hafta boyunca, başlangıç düzeyinde olan deney ve kontrol grubuna yeni bilgilerle ilk defa karşılaştıkları için öncelikle sunuş yoluyla bilgi verilmiş, ardından deney 
grubuna eğitsel oyunlarla, kontrol grubuna ise geleneksel yöntem ve tekniklerle öğretim yapılmıştır. Uygulamanın öncesinde ve sonrasında çalışma grubunu oluşturan öğrencilere Erol (2019) tarafindan geliştirilen "Başlangıç (A1) Düzeyi Türkçe Yeterlik Sınavı" ve "Yabancı Dil Olarak Türkçe Öğrenen Çocuklara Yönelik Tutum Ölçeği”" uygulanmıştır. Uygulama bittikten 4 hafta sonra ise kalıcılık testi uygulanmıştır.

\section{Çalışma Grubu}

Araştırmanın çalışma grubunu, 2018-2019 eğitim-öğretim yılında, Adıyaman Halk Eğitim Merkezinde, başlangıç (A1) düzeyinde yabancı dil olarak Türkçe öğrenen 812 yaş grubundaki Suriyeli öğrenciler oluşturmaktadır. Çalışma grubunun belirlenmesinde uzman görüşüne başvurulmuştur. Yabancı dil olarak Türkçe öğrenim sürecinde öğrencilerin ilgi, istek ve ihtiyaçları, gelişimsel özellikleri ve dil becerilerini etkin kullanabilme yeterlikleri göz önünde bulundurularak başlangıç (A1) düzeyinde 8-12 yaş grubu ile çalışılması uygun görülmüştür. Gönüllü katılımın esas alındığı süreçte, uygulama öncesinde başlangıç (A1) düzeyinde yabancı dil olarak Türkçe öğrenmeye hazır 54 kişilik öğrenci grubu değerlendirilmeye alınmıştır. Öğrencilerden ön testle ilgili güvenilir veri alabilmek amacıyla öğrencilere öncelikle alfabe öğretimi yapılmış ve sonrasında ön test uygulanmıştır. Ön test sonuçlarından hareketle; başarı puanı, cinsiyet, yaş ve Türkiye'de bulunma süresi gibi değişkenler bakımından eşleştirilmiş 20 kişilik deney ve kontrol grubu oluşturulmuştur. Eşleştirilen grupların ön test puan ortalamaları ve standart sapma değerleri Tablo 1'de yer almaktadır.

Tablo 1.

Deney ve Kontrol Grubunun Ön Test Puan Ortalamalarl ve Standart Sapma Dĕgerleri

\begin{tabular}{llcc}
\hline Gruplar & N & ss & $\bar{X}$ \\
\hline Deney Grubu & 20 & 9,75 & 21,55 \\
Kontrol Grubu & 20 & 10,27 & 21,45 \\
\hline
\end{tabular}

Tablo 1 incelendiğinde, deney grubundaki öğrencilerin ön test puan ortalamalarının 21,55 $( \pm 9,75)$, kontrol grubundaki öğrencilerin ön test puan ortalamalarının ise $21,45( \pm 10,27)$ olduğu görülmektedir. Gruplara ait demografik özellikler Tablo 2'de yer almaktadır.

Tablo 2.

Deney ve Kontrol Grubuna Ilişkin Demografik Özellikler

\begin{tabular}{cccccc}
\hline & & \multicolumn{2}{c}{ Deney Grubu } & \multicolumn{2}{c}{ Kontrol Grubu } \\
\multicolumn{2}{c}{ Demografik Özellikler } & $\mathrm{N}$ & $\%$ & $\mathrm{~N}$ & $\%$ \\
\hline \multirow{2}{*}{ Cinsiyet } & Kadın & 13 & $\% 65$ & 12 & $\% 60$ \\
& Erkek & 7 & $\% 35$ & 8 & $\% 40$ \\
\hline \multirow{3}{*}{ Yaş } & 8 Yaş & 3 & $\% 15$ & 4 & $\% 20$ \\
& 9 Yaş & 7 & $\% 35$ & 7 & $\% 35$ \\
& 10 Yaş & 8 & $\% 40$ & 7 & $\% 35$ \\
Türkiye'de & 11 Yaş & 1 & $\% 5$ & 2 & $\% 10$ \\
& 12 Yaş & 1 & $\% 5$ & - & - \\
\hline & 1 Yll ve Daha Az & 2 & $\% 10$ & - & -
\end{tabular}




$\begin{array}{cccccc}\text { Bulunma Süresi } & 2 \text { Yil } & 2 & \% 10 & 5 & \% 25 \\ & 3 \text { Yil } & 6 & \% 30 & 5 & \% 25 \\ 4 \text { Yil } & 4 & \% 20 & 2 & \% 10 \\ 5 \text { Yil } & 4 & \% 20 & 4 & \% 20 \\ 6 \text { Yil } & 2 & \% 10 & 1 & \% 5 \\ 7 \text { Yil } & - & - & 1 & \% 5 \\ & 8 \text { Yil ve Daha Fazla } & - & - & 2 & \% 10\end{array}$

Tablo 2'ye göre, deney grubundaki kadınların oranı $\% 65$, erkeklerin oranı $\% 35$ iken kontrol grubunda kadınların oranı \%60, erkeklerin oranı \%40’tır. Buna göre gruplar cinsiyet bakımından denk durumdadır. Yaş değişkeni bakımından deney grubunda 8 yaşındaki öğrenciler $\% 15,9$ yaşındakiler $\% 35,10$ yaşındakiler $\% 40,11$ yaşındakiler $\% 5$ ve 12 yaşındakiler $\% 5$ orana sahiptir. Kontrol grubunda ise 8 yaşındaki öğrenciler \%20, 9 yaşındakiler \%35, 10 yaşındakiler $\% 35$ ve 11 yaşındakiler $\% 10$ orana sahiptir. Buna göre gruplar yaş değişkeni bakımından benzer bir dağılım göstermektedir. Türkiye'de bulunma süresi bakımından deney grubunda 1 yıl veya daha az kalan öğrenciler \%10, 2 yıl kalanlar \%10, 3 yıl kalanlar \%30, 4 yıl kalanlar \%20, 5 yıl kalanlar $\% 20$ ve 6 yıl kalanlar \%10 orana sahiptir. Kontrol grubunda ise 2 y1l kalan öğrenciler \%25, 3 y1l kalanlar \%25, 4 y1l kalanlar \%10, 5 y1l kalanlar \%20 ve 6 yıl kalanlar \%5, 7 yıl kalanlar \%5, 8 yıl ve daha fazla kalanlar $\% 10$ orana sahiptir. Buna göre gruplar Türkiye'de bulunma süresi değişkenine göre önemli ölçüde benzerlik göstermektedir.

\section{Verilerin Toplanması}

Veri toplama aracı olarak öğrencilerin başarı düzeylerini ve öğrenilenlerin kalıcılığını ölçmek amacıyla Erol (2019) tarafından geliştirilen "Başlangıç (A1) Düzeyi Türkçe Yeterlik Sınavı"; öğrencilerin Türkçe öğrenmeye ilişkin tutumlarını ölçmek amacıyla "Yabancı Dil Olarak Türkçe Öğrenen Çocuklara Yönelik Tutum Ölçeği” kullanılmıştır. Ayrıca araştırmanın uygulama basamağında kullanılan eğitsel oyunlar da Erol (2019) tarafından geliştirilmişsir.

Araştırmanın ön test-son testlerinde kullanılan "Başlangıç (A1) Düzeyi Türkçe Yeterlik Sınavı", Diller İçin Avrupa Ortak Öneriler Çerçevesi'nde (CEFR, 2001; CEFR, 2018) yer alan dil yeterlikleri, düzeyler ve beceri alanları dikkate alınarak dinleme, konuşma, okuma ve yazma bölümlerinden oluşturulmuştur. Okuma bölümü eşleştirme ve çoktan seçmeli sorulardan; dinleme bölümü eşleştirme ve doğru-yanlış türünde sorulardan; yazma bölümü kısa cevaplı sorulardan; konuşma bölümü ise açık uçlu sorulardan oluşturulmuştur. Soruların kapsam geçerliliğini belirlemek üzere belirtke tablosu hazırlanmıştır. Hazırlanan sorular için yabancı dil olarak Türkçe öğretimi alanında uzman dört kişinin, ölçme ve değerlendirme alanında uzman iki kişinin görüşleri alınmıştır. Uzmanlardan alınan görüşler neticesinde başarı testi şekillendirilerek pilot uygulamaya geçilmiştir.

Dört bölümden oluşan taslak sinavın madde analizinde her bölüm kendi içerisinde değerlendirilmiştir. Dört eşleştirme ve dört çoktan seçmeli sorudan oluşan okuma bölümü ile dört eşleştirme ve dört doğru-yanlış türünde sorudan oluşan dinleme bölümünün madde güçlük ve ayırt edicilik düzeyleri ve güvenirlikleri incelenmiş; okuma $(r=, 76)$ ve dinleme $(r=, 73)$ bölümlerinin güvenilir bir ölçme aracı olduğu sonucuna ulaşılmıştır ( $>$,70). Kısa cevaplı 5 sorudan oluşan yazma bölümü ve açık uçlu 5 sorudan oluşan konuşma bölümünün analizinde ise 
Kendall'ın Uyum Katsayısı (Kendall's Coefficient of Concordance) hesaplanmıştır. Kendall'ın Uyum Katsayısı, ikiden fazla değerlendirmecinin, bir grup üzerinde yaptığı değerlendirmeleri sıralayarak, sıralama esasına göre, aralarında anlamlı derecede uyum olup olmadığını sınayan, parametrik olmayan bir testtir (Özdamar, 2013). Değerlendirmeler sonucunda konuşma ( $\mathrm{W}=, 871 ; \mathrm{p}<, 001)$ ve yazma $(\mathrm{W}=$ ,945; p< ,001) bölümünde istatistiksel olarak anlamlı derecede uyum olduğu sonucuna ulaşılmıştır. Puanlar arası uyum incelendikten sonra, açık uçlu soruların puanlama güvenirliğini artırmak amacıyla başlangıç (A1) düzeyi sözlü anlatım, karş1lıklı konuşma ve yazılı anlatım değerlendirme ölçekleri, yabancı dil olarak Türkçe öğretimi alanında çalışan 4 uzmandan görüş alınarak geliştirilmiştir.

Yabancı dil olarak Türkçe öğrenen çocukların Türkçeye yönelik tutumlarını belirlemek amacıyla geliştirilen ölçeğin çalışma grubunu 8-12 yaş aralığında Türkçe öğrenen ana dili Arapça olan öğrenciler oluşturmaktadır. Bu yaş grubunda özellikle A1 ve A2 düzeyinde bulunan öğrencilerin tutumlarını Türkçe olarak tam ifade edemeyebileceği düşünüldüğü için ölçek öğrencilerin ana dilinde, Arapça geliştirilmiştir. 5'li Likert tipinde geliştirilen ölçek, tek boyutlu ve 24 maddeden oluşmaktadır. Geliştirilen ölçeğin genel iç tutarlılık katsayısı $\alpha=, 963$ olarak bulunmuştur. Özdamar'a (2013) göre Cronbach alfa katsayıs1 ,70 ile ,90 aralığındaysa veri toplama aracı yüksek düzeyde güvenilirliğe sahiptir.

Araştırmada kullanılan eğitsel oyunların yapılandırılmasında Diller İçin Avrupa Ortak Öneriler Çerçevesi (CEFR, 2001; CEFR, 2018) temele alınmış; beceri alanı, düzey, yeterlikler gibi temel nitelikler belirlenmiş ve eğitsel oyunlar geliştirilmiştir. Dinleme, karşılıklı konuşma, sözlü anlatım, okuma ve yazma becerileri olmak üzere her bir beceri için ayrı bir eğitsel oyun geliştirilmiştir. Oyunların geliştirilmesinde eğitsel oyunların nitelikleriyle birlikte öğrencinin bilgiyi yapılandırma süreci göz önünde bulundurulmuştur. Oyunlar hazırlık, uygulama ve değerlendirme olmak üzere üç aşamadan oluşturulmuştur. Geliştirilen eğitsel oyunlar yabancı dil olarak Türkçe öğretimi alanında çalışmalar yapan 3 uzman ve eğitsel oyunlarla ilgili çalışmalar yapan 2 uzman tarafindan değerlendirilmiştir. Uzmanlar;

- Öğrenci seviyesi

- Kur düzeyi

- Hedeflenen yeterlik ve kazanımlar

- Hedeflenen beceriler

- Yabancı dil olarak Türkçenin öğretiminin temel ilkeleri

- Öğrencilerin gelişim özellikleri

- Eğitsel oyun nitelikleri gibi ölçütler bakımından oyunları değerlendirmiş ve alınan dönütler neticesinde oyunlara son şekli verilmiştir.

\section{Verilerin Analizi}

Başarı testinden ve tutum ölçeğinden elde edilen verilere SPSS 23. 0 istatistik paket programı kullanılarak aşağıdaki istatistik işlemler uygulanmıştır: 
1. Gruplardaki kişi sayıları 50 kişiden az olduğu için verinin parametrik analizler açısından uygunluğu Shapiro-Wilk normallik testiyle incelenmiştir.

2. Deney ve kontrol grubunda normal dağılım gösteren parametrelerin gruplar arası karşılaştırmasında bağımsız gruplar (Independent Samples) t testi kullanılmıştır.

3. Deney ve kontrol grubunda normal dağılım göstermeyen parametrelerin gruplar arası karşılaştırmasında Mann Whitney-U testi kullanılmıştır.

4. Parametrelerin grup içi ve gruplar arası karşılaştırmalarında iki yönlü varyans analizi (Two Way Anova) kullanılmıştır.

\section{Etik Bildirimi}

$\mathrm{Bu}$ araştırma, 2018-2019 eğitim-öğretim yılında yabancı dil olarak Türkçe öğrenen öğrencilerle gerçekleştirilmiştir. $\mathrm{Bu}$ nedenle çalışmanın etik kurul belgesi bulunmamaktadır. Bununla birlikte, tüm öğrenciler çalışmaya gönüllü olarak katılmışlardır. Araştırmada katılımcıların zararına yönelik herhangi bir uygulama yer almamaktadır. Katılımcılara çalışma sürecinde elde edilen bilgilerin sadece bilimsel bir çalışma için kullanılacağı ve kişisel bilgilerinin gizli tutulacağı ifade edilmiştir.

\section{Bulgular ve Yorum}

Araştırmanın bu bölümünde, toplanan verilerin çözümlenmesi sonucu elde edilen bulgular ve bu bulgulardan hareketle yapılan yorumlara yer verilmiştir.

\section{Birinci Alt Probleme İlişskin Bulgular ve Yorum}

Analiz sürecinde öncelikle deney ve kontrol grubunun ön test, son test ve kalıc1lık testinden aldıkları puanların normal dağılım gösterip göstermediği incelenmiştir. Gruplardaki kişi sayısı 50'den az olduğu için Shapiro-Wilk normallik testi kullanılmıştır. "Başlangıç Düzeyi (A1) Türkçe Yeterlik Sınavı"na ilişkin ön test, son test ve kalıcılık testinin betimsel istatistikleri Tablo 3 'te yer almaktadır.

Tablo 3.

Deney ve Kontrol Grubunun Ön Test, Son Test ve Kalıcılık Testi Puanlarına Ilisşkin Shapiro-Wilk Normallik Testi Sonuçlart

\begin{tabular}{clccc}
\hline Ölçüm & Grup & & Shapiro-Wilk & \\
\hline & & İstatistik & sd & $\mathrm{p}$ \\
\hline \multirow{2}{*}{ Ön test } & Deney &, 806 & 20 &, $001^{*}$ \\
& Kontrol &, 830 & 20 &, $003^{*}$ \\
\hline \multirow{3}{*}{ Son test } & Deney &, 880 & 20 &, $018^{*}$ \\
\hline \multirow{3}{*}{ Kalıc1lik } & Kontrol &, 954 & 20 &, 426 \\
\hline${ }^{*} \mathrm{p}<, 05$ & Deney &, 940 & 20 &, 237 \\
& Kontrol &, 960 & 20 &, 538 \\
\hline
\end{tabular}

Tablo 3 incelendiğinde, ön ve son testte normal dağılım göstermeyen puanların, kalıcılık testinde normal dağılım gösterdiği görülmektedir. Bu sonuçlardan hareketle normal dağılım göstermeyen ön ve son test puanlarının karşılaştırılmasında MannWhitney U testi kullanılmıştır. Normal dağılım gösteren kalıcılık testi puanlarının 
karşılaştırılmasında ise bağımsız gruplar (Independent Samples) $t$ testi kullanılmıştır.

\section{Deney ve kontrol grubunun ön test puanlarının karşılaştırılmasına ilişkin bulgular ve yorum}

Deneysel işlem öncesi çalışma grubuna "Başlangıç Düzeyi (A1) Türkçe Yeterlik Sınavı" ön test olarak uygulanmıştır. Bu testten elde edilen verilerden hareketle eşleştirme yoluyla oluşturulan deney ve kontrol grubunun arasındaki farkın anlamlılı̆̆ Mann-Whitney $U$ testi ile değerlendirilmiştir. Yapılan analize ilişkin sonuçlar Tablo 4'te yer almaktadır.

Tablo 4.

Deney ve Kontrol Grubunun Ön Test Puanlarının Karşılaştırılmasına İlişkin MannWhitney U Testi Sonuçlart

\begin{tabular}{lllllcc}
\hline Ölçüm & Grup & $\mathrm{N}$ & $\bar{X}$ & ss & $\mathrm{z}$ & $\mathrm{p}$ \\
\hline \multirow{2}{*}{ Ön test } & Deney & 20 & 21,55 & 9,75 & \multirow{2}{*}{, 217} & \multirow{2}{*}{, 828} \\
& Kontrol & 20 & 21,45 & 10,27 & & \\
\hline
\end{tabular}

Tablo 4 incelendiğinde, deney grubundaki öğrencilerin ön test başarı puan ortalamasının 21,55 ve kontrol grubu öğrencilerinin ön test başarı puan ortalamasının 21,45 olduğu görülmektedir. Deney ve kontrol grubu öğrencilerinin ön test puan ortalamaları arasındaki fark oldukça azdır. Bu farkın anlamlı olup olmadığına Mann-Whitney U testi ile bakılmış ve gruplar arasında ön test sonucunda $(\mathrm{z}=-217 ; \mathrm{p}>$,05) başarı bakımından anlamlı bir farklılık olmadığı tespit edilmiştir. $\mathrm{Bu}$ verilerden hareketle, eşitlenmiş iki grubun güvenilir verilerle oluşturulduğu söylenebilir.

\section{Deney ve kontrol grubunun son test puanlarının karşılaştırılmasına ilişkin bulgular ve yorum}

Deney ve kontrol grubunun son testten aldığı puanlar arasında anlamlı bir farkın olup olmadığı Mann-Whitney U testi ile değerlendirilmiştir. Yapılan analize ilişkin veriler Tablo 5'te yer almaktadır.

Tablo 5.

Deney ve Kontrol Grubunun Son Test Puanlarının Karşılaştırılmasına İlişkin MannWhitney U Testi Sonuçları

\begin{tabular}{lllcccc}
\hline Ölçüm & Grup & $\mathrm{N}$ & $\bar{X}$ & ss & $\mathrm{z}$ & $\mathrm{p}$ \\
\hline \multirow{2}{*}{ Son test } & Deney & 20 & 82,90 & 13,64 & \multirow{2}{*}{2,031} & \multirow{2}{*}{$042^{*}$} \\
& Kontrol & 20 & 72,40 & 17,24 & & \multirow{2}{*}{} \\
\hline
\end{tabular}

$* \mathrm{p}<, 05$

Tablo 5 incelendiğinde, deney grubuna eğitsel oyunlarla, kontrol grubuna ise geleneksel yöntemlerle öğretim yapıldıktan sonra uygulanan son testte, deney grubunun puan ortalaması $(82,90)$ ile kontrol grubunun puan ortalamasi $(72,40)$ arasında önemli bir farkın olduğu görülmektedir. Bu farkın anlamlı olup olmadığını belirlemek amaciyla yapılan Mann-Whitney $U$ testi sonucunda $(z=-2,031 ; p<, 05)$ bu farkın anlamlı olduğu tespit edilmiştir. Bu sonuçlar, yabancı dil olarak Türkçe 
öğretimi/öğrenimi sürecinde eğitsel oyunlarla öğretimin öğrenci başarısı üzerinde etkili olduğunu göstermektedir. Bu sonuçlardan hareketle, öğrencilere kendilerini keşfetme, temel becerilerini kullanma ve anlamlı öğrenme sağlama firsatı sunan eğitsel oyunların yabancı dil olarak Türkçe öğretiminde/öğreniminde etkili bir teknik olduğu söylenebilir.

\section{Deney ve kontrol grubunun kalıcılık testi puanlarının karşılaştırılmasına ilişkin bulgular ve yorum}

Deney ve kontrol grubunun kalıcılık testinden aldıkları puanlar arasında anlamlı bir farkın olup olmadığı bağımsız gruplar (Independent Samples) t testi ile değerlendirilmiştir. Yapılan analize ilişsin veriler Tablo 6'da yer almaktadır.

Tablo 6.

Deney ve Kontrol Grubunun Kalıcılık Testi Puanlarının Karşılaştırılmasına İlişkin Bağımsız Gruplar t Testi Sonuçları

\begin{tabular}{lllccccc}
\hline Ölçüm & Grup & $\mathrm{N}$ & $\bar{X}$ & ss & sd & t & p \\
\hline Kalıc1lık & Deney & 20 & 74,95 & 13,62 & \multirow{2}{*}{34,698} & \multirow{2}{*}{2,693} & \multirow{2}{*}{$011^{*}$} \\
Testi & Kontrol & 20 & 61,00 & 18,74 & & & \\
\hline$* \mathrm{p}<, 05$ & & & & & &
\end{tabular}

Tablo 6 incelendiğinde, uygulama süreci tamamlandıktan 4 hafta sonra yapılan kalıcılık testinde, deney grubunun puan ortalamasının $(74,95)$, kontrol grubu puan ortalamasından $(61,00)$ daha yüksek olduğu görülmektedir. Deney ve kontrol grubu öğrencilerinin kalıcılık testi puan ortalamaları arasındaki bu farkın anlamlı olup olmadığına bağımsız gruplar $t$ testi ile bakılmış ve bu farkın $(t=2,693 ; p<, 05)$ anlamlı olduğu tespit edilmiştir. Bu durum, yabancı dil olarak Türkçe öğretiminde kullanılan eğitsel oyunların öğrenilenin kalıcılığı üzerinde etkili olduğunu göstermektedir. Bu sonuçlardan hareketle, öğrencilere yaparak-yaşayarak öğrenme ortamları sunan eğitsel oyunların yabancı dil olarak Türkçe öğretimi/öğrenimi sürecinde bilginin yapılandırılmasını ve kalıcı hâle getirilmesini sağlayan önemli bir teknik olduğu söylenebilir.

\section{Deney ve kontrol grubunun ön test, son test ve kalıcılık testi puanlarının çift yönlü karşılaştırılmasına ilişkin bulgular ve yorum}

Uygulamalar sonucunda, dil kazanımları bakımından deney ve kontrol grupları arasında anlamlı bir farkın olup olmadığını ortaya koymak amacıyla çift yönlü varyans (ANOVA) analizi yapılmıştır. $\mathrm{Bu}$ analizin sonuçları Tablo 7'de gösterilmiştir.

Tablo 7.

Deney ve Kontrol Grubunun Ön Test, Son Test ve Kalıcılık Testi Puanlarının Çift Yönlü Varyans (ANOVA) Sonuçlart

\begin{tabular}{llllll}
\hline Varyansın kaynağı & $\begin{array}{l}\text { Kareler } \\
\text { Toplamı }\end{array}$ & sd & $\begin{array}{l}\text { Kareler } \\
\text { ortalamas } 1\end{array}$ & $\mathrm{~F}$ & $\mathrm{p}$ \\
\hline Gruplar Aras1 & 20722,791 & 1 & & & \\
Grup (D/K) & 2009,008 & 1 & 2009,008 & 4,079 &, $050^{*}$ \\
Hata & 18713,783 & 38 & 492,468 & & \\
Ölçüm (Ön test, son & 72084,717 & 1,480 & 48704,001 & 612,572 &, $000^{* * *}$
\end{tabular}




\begin{tabular}{llllll} 
test, kalıcılik test) & & & & & \\
Grup*ölçüm & 1039,617 & 1,480 & 702,416 & 8,835 & ,001** \\
Hata & 4471,667 & 56,242 & 79,507 & 4471,667 & \\
\hline
\end{tabular}

$* \mathrm{p} \leq, 05$

$* * \mathrm{p}<, 01$

$* * * \mathrm{p}<, 001$

Tablo 7'de yer alan değerler incelendiğinde, gruplar arası farkın anlamlı olduğu görülmektedir $(\mathrm{F}=4,079 ; \mathrm{p} \leq, 05)$. Dil kazanımlarına ilişkin grupların ön test, son test ve kalıcılık testi puan ortalamaları arasında anlamlı bir farklılık olduğu görülmektedir $(\mathrm{F}=612,572 ; \mathrm{p}<, 001)$. Deney ve kontrol grubu öğrencilerinin "Başlangıç Düzeyi (A1) Türkçe Yeterlik Sınavı"'ndan aldıkları başarı puanlarının deney öncesinden deney sonrasına anlamlı bir farklılık gösterdiği, yani farklı işlem gruplarında (deney ve kontrol grubu) tekrarlı ölçümler faktörlerinin BDTYS başarı düzeyleri üzerindeki ortak etkilerinin anlamlı olduğu bulunmuştur $(\mathrm{F}=8,835 ; \mathrm{p}<$ ,01). Bu durum, deney grubuna eğitsel oyunlarla öğretimin, kontrol grubuna ise geleneksel yöntem ve tekniklerle öğretimin uygulanmasıyla açıklanabilir.

\section{İkinci Alt Probleme İlişkin Bulgular ve Yorum}

Analiz sürecinde öncelikle deney ve kontrol grubunun "Yabancı Dil Olarak Türkçe Öğrenen Çocuklara Yönelik Tutum Ölçeği”nden aldıkları tutum puanlarının normal dağılım gösterip göstermediği incelenmiştir. Gruplardaki kişi sayısı 50'den az olduğu için Shapiro-Wilk normallik testi kullanılmıştır. Bu teste ilişkin sonuçlar Tablo 8'de yer almaktadır.

Tablo 8.

Deney ve Kontrol Grubunun Tutum Puanlarına Ilişkin Shapiro-Wilk Normallik Testi Sonuçları

\begin{tabular}{clccc}
\hline Ölçüm & Grup & \multicolumn{3}{c}{ Shapiro-Wilk } \\
\hline \multirow{2}{*}{ Ön uygulama } & & İstatistik & sd & p \\
& Deney &, 958 & 20 &, 497 \\
& Kontrol &, 926 & 20 &, 129 \\
\hline \multirow{2}{*}{ Son uygulama } & Deney &, 968 & 20 &, 707 \\
& Kontrol &, 917 & 20 &, 087 \\
\hline
\end{tabular}

Tablo 8 incelendiğinde, ön ve son uygulamada deney ve kontrol grubunun puanlarının normal dağılım gösterdiği görülmektedir. $\mathrm{Bu}$ sonuçlardan hareketle, normal dağılım gösteren ön ve son uygulama tutum puanlarının karşılaştırılmasında bağımsız gruplar t testi kullanılmıştır. Eğitsel oyunlarla öğretim yapılan deney grubu ile geleneksel yöntem ve tekniklerle öğretimin yapıldığı kontrol grubunun uygulama öncesinde ve sonrasında tutumlarında meydana gelen değişiklik Tablo 9'da gösterilmiştir.

Tablo 9.

Deney ve Kontrol Grubunun Tutum Puanlarının Karşılaştırılmasına İlişkin Bă̆ımsız Gruplar t Testi Sonuçları

\begin{tabular}{rrrccccc}
\hline Ölçüm & Grup & $\mathrm{N}$ & $\bar{X}$ & ss & sd & t & p \\
\hline Ön & Deney & 20 & 83,40 & 15,932 & & & \\
\cline { 3 - 5 } & & & & & & &
\end{tabular}




\begin{tabular}{clcccccc}
\hline uygulama & Kontrol & 20 & 81,80 & 17,249 & 37,763 &, 305 &, 762 \\
\hline Son & Deney & 20 & 100,10 & 13,517 & \multirow{2}{*}{30,651} & \multirow{2}{*}{2,691} & \multirow{2}{*}{, $011^{*}$} \\
uygulama & Kontrol & 20 & 84,00 & 23,094 & & & \\
\hline *p $\leq, 05$ & & & & & & &
\end{tabular}

Tablo 9 incelendiğinde, elde edilen verilere göre ön uygulamada deney ve kontrol gruplarının tutum puanı ortalamaları arasında anlamlı bir fark bulunmadığı görülmektedir $(\mathrm{t}=, 305 ; \mathrm{p}>, 05)$. Deneysel işlemden sonra yapılan son uygulamada ise deney ve kontrol grubu puanları arasında anlamlı bir farklılık olduğu görülmektedir $(\mathrm{t}=2,691 ; \mathrm{p}<, 05)$. Bu sonuçlardan hareketle, öğrencilere eğlenceli öğrenme ortamları sunan, öğrencilerin zihinsel, duyuşsal ve sosyal becerilerini geliştiren, güdülenmesini sağlayan eğitsel oyunların öğrenci tutumlarını olumlu yönde etkilediği söylenebilir.

\section{Sonuç, Tartışma ve Öneriler}

Eğitsel oyunların yabancı dil olarak Türkçe öğretiminde kullanımının öğrenci başarısı ve tutumu üzerindeki etkisini tespit etmeyi amaçlayan bu araştırmada, uygulama öncesinde eşleştirme yoluyla oluşturulan deney ve kontrol grubu öğrencilerinin ön test başarı puanları arasında istatistiksel olarak anlamlı bir farklılık bulunamamıştır. Deney grubuna eğitsel oyunlarla, kontrol grubuna ise geleneksel yöntem ve tekniklerle ögrretim yapıldıktan sonra uygulanan son testte, deney grubunun puan ortalaması ile kontrol grubunun puan ortalaması arasında önemli bir farkın bulunduğu ve bu farkın istatistiksel olarak anlamlı olduğu tespit edilmiştir. Deney grubu lehine olan bu anlamlı farklılık, yabancı dil olarak Türkçe öğretiminde kazanımlara ulaşmada, eğitsel oyunlarla yapılan öğretimin geleneksel öğretime göre daha başarılı olduğu sonucunu ortaya çıkarmaktadır.

İlgili alanyazında yapılan araştırmaların büyük bir kısmının ulaştığı sonuç ile bu araştırmanın sonucu aynı doğrultudadır. Yabancı dil olarak Türkçe öğretiminde eğitsel oyunların kullanımı ile ilgili deneysel çalışmalarda (Al Khudhur, 2016; Dervişoğulları, 2008), ana dili olarak Türkçe öğretiminde eğitsel oyunların kullanımı ile ilgili deneysel çalışmalarda (Varan, 2017; Arıci, 2017; Baştuğ, 2015; Gülsoy, 2013; Gedik, 2012), yabancı dil olarak İngilizce ve Almanca öğretiminde eğitsel oyunların kullanımı ile ilgili deneysel çalışmalarda (Al Zangana, 2018; Işık, 2016; Mubaslat, 2012; Chou, 2012; Alemi, 2010; Özbal, 2009; Şenergüç, 2007; Gömleksiz, 2005) eğitsel oyunlarla öğretimin uygulandığg deney grubu ile geleneksel öğretimin uygulandığı kontrol grubu arasında, deney grubu lehine anlamlı farklılıklar ortaya çıkmış ve eğitsel oyunların kullanıldığı grupların daha başarılı olduğu tespit edilmiştir. Ataöver (2005), "Ergenlere Oyunlarla Íngilizce Dil Bilgisi Öğretimi" adlı çalışmasında deneysel işlem sonucu dil bilgisi oyunları ile ders yaptırılan öğrenci grubunun puan ortalamasının geleneksel öğretim uygulanan öğrenci grubuna göre daha yüksek olmadığını tespit etmiş ve bu durumu öğrencilerin eğitsel oyunlarla öğretime alışkın olmaması ve içinde bulundukları yaş grubunun problemli olması gibi gerekçelere dayandırmıştır.

Uygulama süreci tamamlandıktan 4 hafta sonra yapılan kalıcılık testinde, deney grubunun puan ortalamasının, kontrol grubu puan ortalamasından daha yüksek olduğu ve bu farkın istatistiksel olarak deney grubu lehine anlamlı olduğu tespit 
edilmiştir. Bu durumda, yabancı dil olarak Türkçe öğretiminde kullanılan eğitsel oyunların geleneksel öğretime göre öğrenilenin kalıcılığı üzerinde daha etkili olduğu sonucuna varılmıştır. Ana dili olarak Türkçe öğretiminde eğitsel oyunların kullanımı ile ilgili yapılan deneysel çalışmalarda (Arıci, 2017; Gedik, 2012) öğrenilen bilgilerin kalıcılığıyla ilgili benzer sonuçlar ortaya çıkmıştır. Taheri (2014), yabancı dil öğretiminde öğrenilenlerin kalıcılığıyla ilgili önemli bir çalışma yapmıştır. Dil öğrenimde kullanılan oyunların ilkokul öğrencilerinin İngilizce kelimeleri öğrenimine etkisini araştırmayı amaçlayan çalışmasında, aynı seviyede olan deney grubu ve kontrol grubuna 4 hafta süren uygulama sonrasında son test uygulamış, 2 hafta sonra da kalıcılık testi yapmıştır. Kalıcılık testinden 4 hafta sonra ise bir daha kalıcılık testi yapmış ve zaman geçtikçe kelime hatırlamada oyunların geleneksel tekniklere göre daha kalıcı bilgi sağladığı sonucuna ulaşmıştır. Bu bağlamda, öğrenilenlerin kalıcılığı bakımından yapılan araştırmalar ile bu araştırmanın sonucunun örtüştüğü görülmektedir.

Eğitsel oyunların yabancı dil olarak Türkçe öğretiminde kullanımının öğrenci tutumuna etkisiyle ilgili olarak, uygulama öncesi gerçekleştirilen ön uygulamada deney ve kontrol gruplarının tutum puanı ortalamaları arasında anlamlı bir fark bulunmadığı, deneysel işlemden sonra yapılan son uygulamada ise deney ve kontrol grubu tutum puanlarında istatistiksel olarak anlamlı bir farklılık olduğu tespit edilmiştir. Ön uygulamada deney ve kontrol grubu öğrencilerinin yabancı dil olarak Türkçe öğrenmeye yönelik tutum puanı ortalamalarının birbirine yakın olduğu, fakat deneysel işlem sonrası yapılan son uygulamada deney grubu öğrencilerinin kontrol grubu öğrencilerinden daha yüksek tutum puanına sahip olduğu belirlenmiştir. $\mathrm{Bu}$ bağlamda, eğitsel oyunlarla öğretimin yabancı dil olarak Türkçe öğrenmeye yönelik tutumu olumlu yönde etkilediği, geleneksel öğretime göre daha etkili olduğu sonucuna ulaşılmıştır. Chou (2012), oyun, şarkı ve hikâyelerin yabancı dil olarak İngilizce öğrenim sürecinde kelime hazinesinin zenginleştirilmesine etkisini incelediği çalışmasında, oyunların öğrencinin tutumunu olumlu yönde etkilediği sonucuna varmıştır. Kara (2010), yabancı dil olarak Türkçe öğretiminde uygulanan eğitsel oyunlarla ile ilgili gözleme dayalı nitel bir çalışma yapmış ve uygulanan oyun etkinlikleri sayesinde öğrencilerin dil öğrenmeye yönelik olumlu tutum geliştirdiğini gözlemlemiştir. Özbal (2009), Almanca öğreniminde eğitsel oyunların kullanımıyla ilgili deneysel çalışmasında, ön testte kontrol ve deney grubunun tutum puanlarının birbirine yakın olduğunu, son testte ise deney grubu tutum puanlarının kontrol grubuna göre daha yüksek olduğu sonucuna ulaşmıştır. Al Neyadi (2007), kelime öğretiminde oyunların etkisini belirlemek amaciyla yaptı̆̆ eylem araştırmasında, eğitsel oyunların öğrenci tutumlarını olumlu yönde etkilediği sonucuna ulaşmıştır. Alanyazındaki bu sonuçlar, araştırma sonuçlarını desteklemektedir.

Etkili ve kalıcı dil öğreniminde dilin kuralları değil, kullanımı önemsenmektedir. $\mathrm{Bu}$ bakımdan gerçekçi iletişim ortamları oluşturan, dilin anlamlı bir bağlam içerisinde kullanımını sağlayan eğitsel oyunlar, dil öğrenimi için vazgeçilmez etkinliklerdir. Bu etkinliklerde öğrenciler özgüven kazanarak sorumluluk alır; dilsel, zihinsel ve sosyal becerilerini geliştirir ve öğrenme sürecinin önemli bir parçası haline gelir. 
Dil öğrenim sürecinde öğrencilerin etkinliklerde aktif olmaları önemli olduğu gibi etkinlik sonrası tekrar yapmaları da önemlidir. Sınıf içi dil etkinliklerine katılan öğrencilerin öğrendiklerini tekrar etmeleri çoğunlukla sınıf dişında gerçekleştirdikleri bağımsız etkinliklerle mümkün olmaktadır. Eğitsel oyunlar, bu bağımsız etkinlikleri gerçekleştirebilmek için kullanılabilecek önemli bir tekniktir. Çünkü öğrencileri güdüleyen, sorumluluk alma, iş birliği yapma, uzlaşma, uyum sağlama, düşünme ve karar verme gibi becerilerini geliştiren eğitsel oyunlar, öğrencilere bağımsız iş yapabilme becerisi de kazandırmaktadır. Eğitsel oyunlar sayesinde öğrenme sürecinde istekli olan ve bağımsızlık becerilerini geliştiren öğrenciler rahatlıkla sınıf dışı etkinlikler düzenleyebilmekte, öğrenmeleri tekrar edebilmekte ve bağımsı öğrenmeler gerçekleştirebilmektedir.

Araştırmanın bulgularına bağlı olarak uygulamaya yönelik şu öneriler sunulabilir:

- Öğrencilerin ilgi, istek ve beklentileri doğrultusunda farklı düzey ve yaş gruplarına yönelik, temel dil becerilerini geliştiren yapılandırılmış eğitsel oyunlar geliştirilebilir.

- Yabancı dil olarak Türkçe öğretimi alanında hazırlanacak öğretim programlarında eğitsel oyunlara yer verilebilir.

- Yabancı dil olarak Türkçe öğretimine yönelik hazırlanacak ders kitaplarında eğitsel oyunlara yer verilebilir.

- Eğitsel oyunlarda kullanılmak üzere öğrencinin ilgisini çekebilecek, bağımsız öğrenmelerini destekleyebilecek materyaller hazırlanabilir.

- Teknolojinin her tarafi kuşattığı bu çağın insan hayatındaki yeri göz önünde bulundurularak, yabancı dil olarak Türkçe öğretiminde kullanılmak üzere bilgisayar destekli, internet tabanlı eğitsel oyunlar geliştirilebilir.

- Yabancı dil olarak Türkçe öğretiminde eğitsel oyunların kullanımı ile ilgili eğiticinin eğitimi programları düzenlenebilir veya bu alanda yapılan eğiticinin eğitimi sertifika programlarına yabancı dil olarak Türkçe öğretiminde eğitsel oyunların kullanımı ile ilgili dersler konulabilir.

Araştırmanın bulgularına bağlı olarak araştırmacılara yönelik şu öneriler sunulabilir:

- $\mathrm{Bu}$ araştırma, 8-12 yaş grubu ve başlangıç (A1) düzeyine yönelik kazanımlarla sınırlıdır. Araştırmacılar farklı yaş grupları ve düzeylerde eğitsel oyunların kullanımıyla ilgili araştırma yapabilir ve ulaştığı sonuçları bu araştırmayla karşılaştırılabilir.

- $\mathrm{Bu}$ araştırmada, eğitsel oyunların yabancı dil olarak Türkçe öğretiminde kazanımlara ulaşmada, öğrencinin başarısına, derse karşı tutumuna ve öğrenilenlerin kalıcılığına etkisi incelenmiştir. Kaygı, güdülenme ve özgüven gibi değişkenler dikkate alınarak yeni çalışmalar yapılabilir.

- $\mathrm{Bu}$ araştırmada yabancı dil olarak Türkçe öğretiminde eğitsel oyunların kullanımı ile ilgili öğrenci görüşleri alınmıştır. Farklı diller de dâhil olmak üzere yabancı dil öğretiminde eğitsel oyunların kullanımı ile ilgili öğretmen görüşleri alınabilir ve karşılaştırılabilir. 
- Dil öğretimi üzerine çalışmalar yapan ulusal ve uluslararası resmî kurumlar ve sivil toplum kuruluşlarıyla iş birliği içerisinde yabancı dil olarak Türkçe öğretiminde eğitsel oyunların kullanımı ile ilgili projeler yapılabilir.

- Yabanci dil olarak Türkçe öğretiminde öğrenciyi merkeze alan, öğrencilerin dilsel, zihinsel, duygusal ve sosyal becerilerini geliştiren farklı yöntem ve tekniklerle ilgili araştırmalar yapılabilir.

\section{Çıkar Çatışması ve Etik Bildirimi}

Yazarlar, aralarında çıkar çatışması bulunmadığını ve tüm araştırmacıların çalışmaya katkı sunduğunu beyan etmiştir. Yazarlar, tüm etik kurallara uyduklarını bildirmiştir.

\section{Kaynakça}

Al Khudhur, M. (2016). Yapım eklerinin öğretiminde eğitsel oyun temelli bir model önerisi: Kerkük Türkmenleri örneklemi [Yayımlanmamış yüksek lisans tezi]. Gazi Üniversitesi.

Al Neyadi, O. S. (2007). The effects of using games to reinforce vocabulary learning. http://citeseerx.ist.psu.edu/viewdoc/download?doi=10.1.1.696.2297\&rep=rep1\&type=pdf adresinden 10.05.2019 tarihinde alınd.

Al Zangana, A. F. A. (2018). Eğitsel oyunların ve cinsiyetin yabancı dil öğrenenler olarak beş yaşındaki üzerine etkisi [Yayımlanmamış yüksek lisans tezi]. İstanbul Aydın Üniversitesi.

Âlemi, M. (2010). Educational games as a vehicle to teaching vocabulary. Modern Journal of Applied Linguistics, 2(6), 425-438.

Arıci, B. (2017). Eğitsel oyunların Almanya'da yaşayan Türk çocuklarının Türkçe öğrenme başarılarına etkisi [Yayımlanmamış doktora tezi]. Atatürk Üniversitesi.

Ataöver, S. (2005). Ergenlere oyunlarla İngilizce dil bilgisi öğretimi [Yayımlanmamış yüksek lisans tezi]. Abant İzzet Baysal Üniversitesi.

Avrupa Konseyi. (2001). Common European framework of reference for languages: Learning, teaching, assessment. Cambridge University Press.

Avrupa Konseyi. (2018). Common European framework of reference for languages: Learning, teaching, assessment. Companion volume with new descriptors. https://rm.coe.int/cefr-companion-volume-with-new-descriptors-2018/1680787989 adresinden 10.05.2019 tarihinde alınd.

Baştuğ, S. D. (2015). Eğitsel oyunlarla desteklenen dikte etkinliklerinin öğrencilerin dikte becerilerine etkisinin incelenmesi [Yayımlanmamış yüksek lisans tezi]. Erciyes Üniversitesi.

Bumpass, F. Y. (1963). Teaching young students English as a foreign language. American Book Company.

Chou, M. (2012). Assessing English vocabulary and enhancing young English as a foreign language (EFL) learners' motivation through games, songs and stories. Education 3-13: International Journal of Primary, Elementary and Early Years Education, 42(3), 284-297. https://doi.org/10.1080/03004279.2012.680899

Demirel, Ö. (2011). Yabancı dil öğretimi. Pegem Akademi.

Dervişoğulları, N. (2008). Yabancı dil olarak Türkçe öğretilen sinıflarda oyunlarla sözcük ögretimi [Yayımlanmamış yüksek lisans tezi]. Ankara Üniversitesi. 
Erdem, İ., \& Aycan, E. (2017). Dil öğretiminde oyunun yeri ve uygulama basamakları. H. Develi, C. Yıldız, M. Balcı, İ. Gültekin ve D. Melanlığlu (Editörler), Uygulamalı Türkçenin yabancı dil olarak öğretimi el kitabı (s. 361-392) içinde. İstanbul: Kesit Yayınları.

Erol, S. (2019). Yabancı dil olarak Türkçe öğretiminde eğitsel oyunların kullanımı [Yayımlanmamış doktora tezi]. İnönü Üniversitesi.

Fraenkel, J. R., \& Wallen, N. E. (2006). How to design and evaluate research in education. McGraw-Hill.

Gedik, M. (2012). Ortaokul ikinci sınıf ögrrencilerinin temel dil becerilerinin gelişstirilmesinde eğitsel oyunların başarı ve kalıcılığa etkileri [Yayımlanmamış doktora tezi]. Atatürk Üniversitesi.

Göçer, A., \& Moğul, S. (2011), Türkçenin yabancı dil olarak öğretimi ile ilgili çalışmalara genel bir bakış. Turkish Studies, 6(3), 797-810.

Gömleksiz, M. N. (2005). Oyun ile İngilizce öğretiminin uygulanması ve öğrenci başarısına etkisi. Kırgızistan Manas Üniversitesi Sosyal Bilimler Dergisi, 14, 179-195.

Gülsoy, T. (2013). 6. slnıf öğrencilerinin kelime hazinesinin gelişstirilmesinde eğitsel oyunların etkisi [Yayımlanmamış yüksek lisans tezi]. Niğde Üniversitesi.

Iş1k, İ. (2016). İlkokul 3. sınlf öğrencilerine eğitsel oyunlar ile İngilizce kelime öğretiminin akademik başarıya etkisi [Yayımlanmamış yüksek lisans tezi]. Bartın Üniversitesi.

Kara, M. (2010). Oyunlarla yabancılara Türkçe öğretimi. Türklük Bilimi Araştırma Dergisi (TÜBAR), 27, 407-421.

Larsen Freeman, D. (2000). Techniques and principles in language teaching. Oxford University Press.

Lee, S. K. (1995). Creative games for the language class. Forum, 33(1), 35-48.

Lee, W. R. (1986). Language teaching games and contests. Oxford University Press.

Mubaslat, M. M. (2012). The effect of using educational games on the students' achievement in English language for the primary stage. https://files.eric.ed.gov/fulltext/ED529467.pdf adresinden 25.05.2019 tarihinde alınd1.

Özbal, B. (2009). İlköğretim okullarındaki yabancı dil ögretiminde eğitsel oyunların yeri ve önemi [Yayımlanmamış yüksek lisans tezi]. Selçuk Üniversitesi.

Özdamar, K. (2013). Paket programlar ile istatistiksel veri analizi. Nisan Kitabevi.

Şenergüç, G. (2007). Yetişkinlere kelime öğretiminde oyunların kullanımı [Yayımlanmamış yüksek lisans tezi]. Selçuk Üniversitesi.

Simpson, A. (2015). Using games in the language classroom. http://research.sabanciuniv.edu/26774/1/using-games-in-the-language-classroom.pdf adresinden 23.05.2019 tarihinde alındı.

Taheri, M. (2014). The effect of using language games on vocabulary retention of Iranian elementary EFL learners. Journal of Language Teaching and Research, 5(3), 544-549. https://doi.org/10.4304/jltr.5.3.544-549

Taşpınar, M. (2012). Kuramdan uygulamaya ögretim ilke ve yöntemleri. Elhan Kitap Yayın Dağıtım. https://doi.org/10.14527/9786052411032 
Uberman, A. (1998). The use of games for vocabulary presentation and revision. English Teaching Forum, 36(1), 20-27.

Varan, S. (2017). İlkokul 4. sinıf öğrencilerinin zihinsel sözlüğünü gelişstirmede eğitsel oyunların etkisi [Yayımlanmamış yüksek lisans tezi]. Bartın Üniversitesi.

Vardar, Berke (2002). Açıklamalı dilbilim terimleri sözlüğ̈̈. Multilingual.

Wright, A., Betteridge, D., \& Buckby, M. (2006). Games for language learning. Cambridge University Press.

\section{Extended Abstract}

Recently, the interest and need for Turkish has increased due to factors such as tourism, trade and education, especially migration; Important studies have been carried out in the field of teaching / learning Turkish as a foreign language. In this process, individuals with different mother tongue, age group and characteristics faced some problems while learning Turkish, and the methods and techniques used in teaching Turkish as a foreign language were questioned. As a result of this inquiry, it was focused on student-centered, communication-based teaching methods and techniques that take into account individual differences and enable permanent learning by enabling the use of basic skills.

Ensuring permanent learning by using basic skills in language teaching is not an easy process for the student. In order for the student to be successful in this process, it must be interested in learning, make an effort and continue this effort for a long time. In this context, educational games are indispensable activities that motivate students and help them by creating intensive and meaningful learning environments (Wright, Betteridge \& Buckby, 2006: 2; Lee, 1995: 35). In this context, the aim of the study was determined as determining the effect of educational games on students' achievement in teaching Turkish as a foreign language, their attitude towards the lesson and the permanence of the learned.

A quasi-experimental design with paired pretest-posttest control group was used in the study. In the paired pre-test-post-test control group model, there are two groups, one of which is experimental group and the other is control group, formed by matching. In the matching process, variables such as age and gender to be used in the study are also considered along with the success score. Matched individuals are randomly assigned to the control and experimental groups. Measurements are made before and after the experimental procedure in both groups (Fraenkel \& Wallen, 2006). During the research process, for 5 weeks, the experimental and control groups, who were at the beginner level, were informed firstly by presentation, since they encountered new information for the first time, then the experimental group was taught with educational games and the control group with traditional methods and techniques. Before and after the application, the "Beginner (A1) Level Turkish Proficiency Exam" and "Attitude Scale for Children Learning Turkish as a Foreign Language" developed by Erol (2019) were applied to the students who formed the study group. 4 weeks after the end of the application, the retention test was applied. 
The study group of the study consisted of Syrian students aged 8-12 who learned Turkish as a foreign language at the beginning (A1) level in Adiyaman Public Education Center in the 2018-2019 academic year. In the study, no statistically significant difference was found between the pre-test success scores of the experimental and control group students, which were formed by matching before the application. In the post-test applied after teaching the experimental group with educational games and the control group with traditional methods and techniques, it was determined that there was a significant difference between the average score of the experimental group and the average score of the control group, and this difference was statistically significant. This significant difference in favor of the experimental group reveals that teaching with educational games is more successful than traditional teaching in achieving gains in teaching Turkish as a foreign language. In the retention test performed 4 weeks after the completion of the application process, it was determined that the average score of the experimental group was higher than the average score of the control group and this difference was statistically significant in favor of the experimental group. In this case, it was concluded that educational games used in teaching Turkish as a foreign language are more effective on the retention of what is learned than traditional teaching.

Regarding the effect of the use of educational games in teaching Turkish as a foreign language on student attitude, there was no significant difference between the attitude scores of the experimental and control groups in the pre-application performed before the application, and a statistically significant difference in the attitude scores of the experimental and control groups in the final application after the experimental process. It has been determined. In the pre-application, it was determined that the experimental and control group students' attitude scores towards learning Turkish as a foreign language were close to each other, but in the final application after the experimental process, the experimental group students had higher attitude scores than the control group students. In this context, it has been concluded that teaching with educational games positively affects the attitude towards learning Turkish as a foreign language and is more effective than traditional teaching. 